\title{
Identification of KIF11 as a Novel Target in Meningioma
}

\author{
Gerhard Jungwirth ${ }^{1}\left(\mathbb{D}\right.$, Tao Yu ${ }^{1}$, Mahmoud Moustafa ${ }^{2,3}$, Carmen Rapp ${ }^{1}$, Rolf Warta ${ }^{1}(\mathbb{D}$, \\ Christine Jungk ${ }^{1}$, Felix Sahm ${ }^{4}$, Steffen Dettling ${ }^{1}$, Klaus Zweckberger ${ }^{1}$, Katrin Lamszus ${ }^{5}$, \\ Christian Senft ${ }^{6}$, Mario Loehr ${ }^{7}$, Almuth F. Keßler ${ }^{7}$, Ralf Ketter ${ }^{8}$, Manfred Westphal ${ }^{5}$, \\ Juergen Debus ${ }^{2}$, Andreas von Deimling ${ }^{4}$, Matthias Simon ${ }^{9}$, Andreas Unterberg ${ }^{1}$, \\ Amir Abdollahi ${ }^{2}$ (D) and Christel Herold-Mende ${ }^{1, *}$
}

1 Division of Experimental Neurosurgery, Department of Neurosurgery, University of Heidelberg, INF 400, D-69120 Heidelberg, Germany; gerhard.jungwirth@med.uni-heidelberg.de (G.J.); tao.yu@med.uni-heidelberg.de (T.Y.); carmen.rapp@med.uni-heidelberg.de (C.R.); rolf.warta@med.uni-heidelberg.de (R.W.); christine.jungk@med.uni-heidelberg.de (C.J.); steffen.dettling@gmail.com (S.D.); klaus.zweckberger@med.uni-heidelberg.de (K.Z.); andreas.unterberg@med.uni-heidelberg.de (A.U.); H.Mende@med.uni-heidelberg.de (C.H.-M.)

2 Department of Radiation Oncology, University of Heidelberg, INF 400, D-69120 Heidelberg, Germany; Mahmoud.Moustafa@med.uni-heidelberg.de (M.M.); Juergen.Debus@med.uni-heidelberg.de (J.D.); Amir.Abdollahi@med.uni-heidelberg.de (A.A.)

3 Department of Clinical Pathology, Suez Canal University, 41522 Ismailia, Egypt

4 Department of Neuropathology, Institute of Pathology, University of Heidelberg, German Cancer Consortium, CCU Neuropathology, German Cancer Research Center, INF 224, D-69120 Heidelberg, Germany; Felix.Sahm@med.uni-heidelberg.de (F.S.); Andreas.vonDeimling@med.uni-heidelberg.de (A.v.D.)

5 Department of Neurosurgery, University Medical Center Hamburg Eppendorf, Martinistr 52, D-20246 Hamburg, Germany; lamszus@uke.uni-hamburg.de (K.L.); westphal@uke.de (M.W.)

6 Department of Neurosurgery, University Hospital, Goethe University, Schleusenweg 2, D-60528 Frankfurt am Main, Germany; c.senft@med.uni-frankfurt.de

7 Department of Neurosurgery, University Hospital Wuerzburg, Josef-Schneider-Str 2, D-97080 Wuerzburg, Germany; loehr_m1@ukw.de (M.L.); kessler_a1@ukw.de (A.F.K.)

8 Department of Neurosurgery, Saarland University, Medical School, Kirrberger Str, D-66421 Homburg, Germany; Ralf.Ketter@uks.eu

9 Department of Neurosurgery, Bethel Clinic, Burgsteig 13, D-33617 Bielefeld, Germany; matthias.simon@evkb.de

* Correspondence: H.Mende@med.uni-heidelberg.de; Tel.: +49-6221-5637927

Received: 14 March 2019; Accepted: 11 April 2019; Published: 15 April 2019

Abstract: Kinesins play an important role in many physiological functions including intracellular vesicle transport and mitosis. The emerging role of kinesins in different cancers led us to investigate the expression and functional role of kinesins in meningioma. Therefore, we re-analyzed our previous microarray dataset of benign, atypical, and anaplastic meningiomas $(n=62)$ and got evidence for differential expression of five kinesins (KIFC1, KIF4A, KIF11, KIF14 and KIF20A). Further validation in an extended study sample $(n=208)$ revealed a significant upregulation of these genes in $\mathrm{WHO}^{\circ} \mathrm{I}$ to ${ }^{\circ} \mathrm{III}$ meningiomas (WHO ${ }^{\circ} \mathrm{I} n=61, \mathrm{WHO}^{\circ} \mathrm{II} n=88$, and $\mathrm{WHO}^{\circ} \mathrm{III} n=59$ ), which was most pronounced in clinically more aggressive tumors of the same WHO grade. Immunohistochemical staining confirmed a WHO grade-associated upregulated protein expression in meningioma tissues. Furthermore, high mRNA expression levels of KIFC1, KIF11, KIF14 and KIF20A were associated with shorter progression-free survival. On a functional level, knockdown of kinesins in Ben-Men-1 cells and in the newly established anaplastic meningioma cell line NCH93 resulted in a significantly inhibited tumor cell proliferation upon siRNA-mediated downregulation of KIF11 in both cell lines by up to $95 \%$ and $71 \%$, respectively. Taken together, in this study we were able to identify the prognostic and functional role of several kinesin family members of which KIF11 exhibits the most promising 
properties as a novel prognostic marker and therapeutic target, which may offer new treatment options for aggressive meningiomas.

Keywords: meningioma; KIF; kinesin; KIF11; NCH93

\section{Introduction}

Meningiomas (MGMs) are tumors of the central nervous system and account for one-third of all brain tumors. They are assumed to arise from the meningeal coverings of the brain and the spinal cord [1]. Meningiomas are histologically classified according to the World Health Organization's (WHO) grading scheme [2]. Nearly $80 \%$ of meningiomas are benign, corresponding to $\mathrm{WHO}^{\circ} \mathrm{I}, 10-15 \%$ are atypical $\left(\mathrm{WHO}^{\circ} \mathrm{II}\right)$, and only $2-5 \%$ are anaplastic meningiomas $\mathrm{WHO}^{\circ} \mathrm{III}$. Their incidence ranges from 1.3 per 100,000 to 7.8 per 100,000 [3]. Clinical outcome strongly depends on the WHO grade. While patients with benign meningiomas have five-year survival rates of $92 \%$, it decreases in atypical meningiomas to $78 \%$, and in patients with $\mathrm{WHO}^{\circ} \mathrm{III}$ meningiomas, survival rates drop down to 47\% [4-7]. Therapy options include observation and maximal safe resection. Residual or recurring tumors are usually treated with conventional radiotherapy while all tested chemotherapeutic agents failed to show any significant effect in the treatment of aggressive meningiomas [8].

Recent studies revealed distinct but in part mutually exclusive genetic alterations in meningiomas including NF2, TRAF7, AKT1, SMO, KLF4, POLR2A, PIK3CA and TERT promoter mutations [9-14]. The identification of these mutations led to the investigation of inhibitors targeting proteins such as AKT1, SMO, mTOR and FAK [15-17]. Based on these findings, several clinical trials have been initiated (NCT02523014; NCT03071874; NCT02831257; and EORTC-1320).

The kinesin superfamily (KIF) members are highly conserved motor proteins, which are subdivided into 14 families (Kinesin 1-14A/B) [18-20]. Their motor domain enables binding and stepping across microtubules by converting the chemical energy of ATP in mechanical ATP hydrolysis into a mechanical force [21,22]. KIF proteins play an important role in cellular functions including mitosis and intracellular transport of vesicles and organelles [22,23]. Due to overexpression of certain motor kinesins such as KIF11, additional outward forces can be generated during mitosis leading to premature separation of sister chromatids and an unequal distribution of chromosomes and thus may cause aneuploid daughter cells $[22,24]$. The resulting genetic instability can cause progression of cancer, for example through an increased invasion and the development of metastasis [25]. Accordingly, kinesin proteins have been shown to be upregulated and may be associated with a reduced progression-free survival in several cancer types including colorectal cancer [26], melanoma [27], retinoblastoma [28], breast [29], lung [30], pancreatic [31], laryngeal [32], hepatocellular [33], ovarian carcinoma and glioma [34-36]. However, data on the functional expression of kinesins in meningiomas are missing.

In the present study, we identified a WHO-dependent upregulated mRNA expression of five members of the kinesin family by re-analyzing a previous transcriptome dataset of meningiomas [37]. Their differential expression could be confirmed at the mRNA and protein level. In addition, in the presence of higher mRNA levels, we could demonstrate a poorer survival for several of the kinesin family members. However, only knockdown of KIF11 resulted in a markedly reduced tumor cell proliferation in Ben-Men-1 cells and the newly established anaplastic NF2-mutated meningioma cell line NCH93, proposing KIF11 as a novel prognostic marker and therapeutic target.

\section{Results}

\subsection{Kinesin mRNA Levels Increase with WHO Grade of Meningiomas}

In a previous study, we assessed transcriptome microarray data of 62 meningiomas including a substantial number of rare higher-grade tumors $\left(\mathrm{WHO}^{\circ} \mathrm{I} n=20, \mathrm{WHO}^{\circ} \mathrm{II} n=14\right.$ and $\mathrm{WHO}^{\circ} \mathrm{III}$ 
$n=28$ ) [37]. By re-analyzing our dataset for the expression of members of the kinesin family, we identified significant differential gene expression of five kinesins: KIFC1, KIF4A, KIF11, KIF14 and KIF20A (Supplementary Table S3) (fold change $>1.25$ and $p<0.01$ ). We next sought to validate the differential expression of these genes in an extended set of meningioma tissue samples by quantitative real-time PCR (qRT-PCR). In total, we used RNA of $61 \mathrm{WHO}^{\circ} \mathrm{I}, 88 \mathrm{WHO}^{\circ} \mathrm{II}$ and 59 $\mathrm{WHO}^{\circ} \mathrm{III}$ meningiomas. Patient characteristics are presented in Table 1. In accordance with the microarray data, we observed a significant $\mathrm{WHO}$ grade-associated increase of all tested kinesin genes $(p<0.001 ;$ Figure 1A).

A
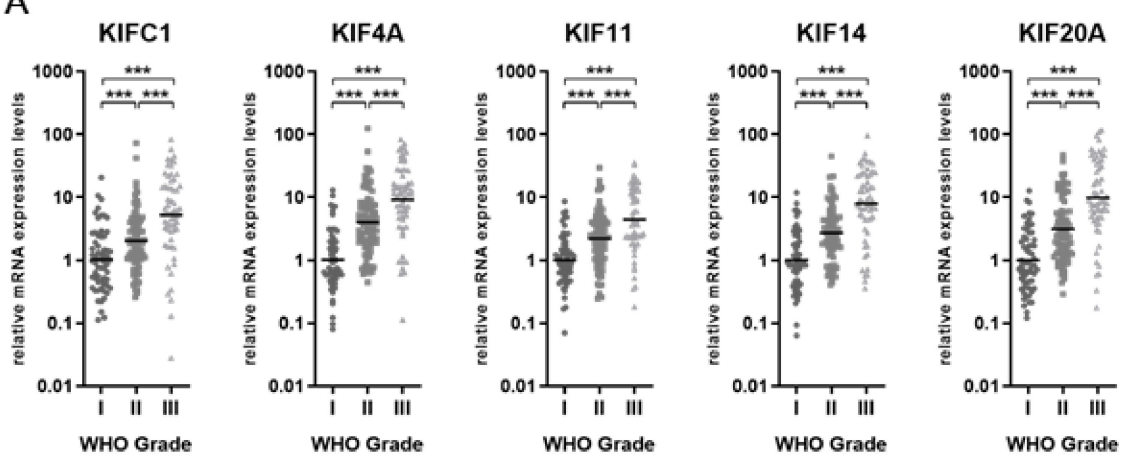

B

KIFC1
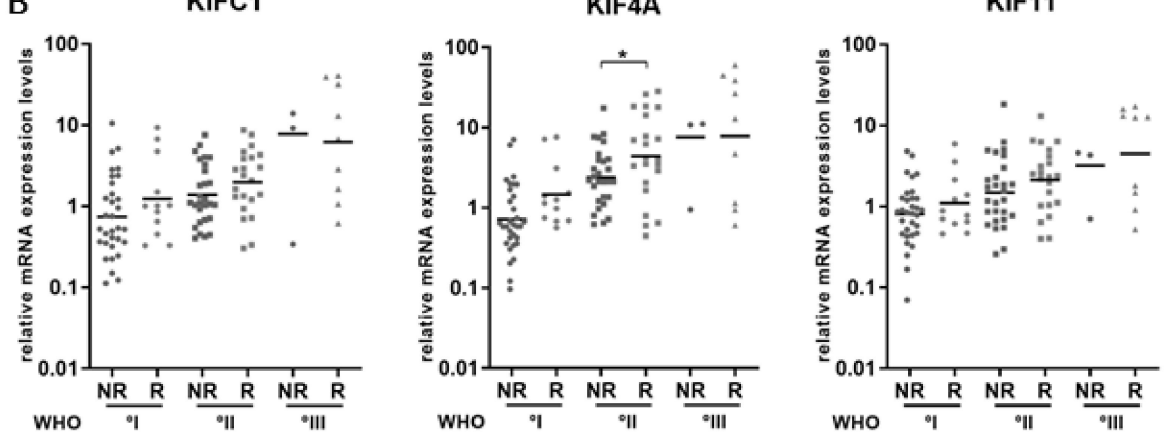

KIF14
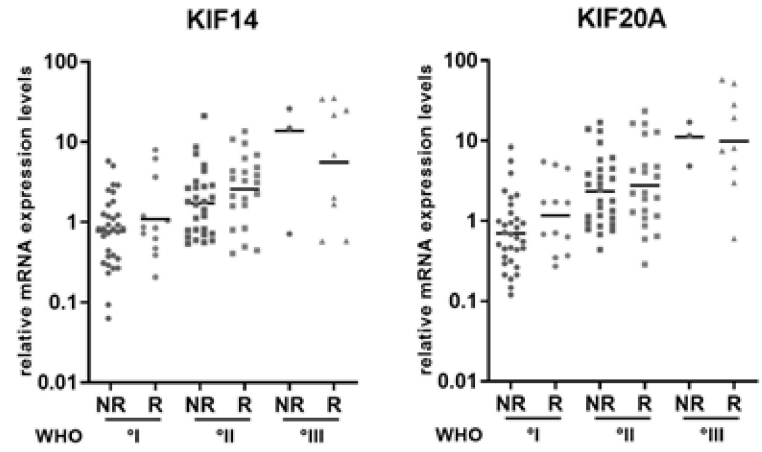

Figure 1. mRNA expression levels of kinesin family members increase with WHO grade in meningiomas. (A) qRT-PCR expression data for KIFC1, KIF4A, KIF11, KIF14A and KIF20A are shown. mRNA levels were normalized to the mean of the meningioma $\mathrm{WHO}^{\circ} \mathrm{I}$ samples $(n=61)$. (B) Kinesin mRNA expression according to the future clinical course of the disease. Primary meningioma tissue samples were grouped into non-recurrent (NR) (follow-up period $\geq 60$ months), and clinically aggressive tumors presenting with recurrent meningiomas during the observation time (R) of each WHO grade. Significance levels: ${ }^{*} p<0.05,{ }^{* * *} p<0.001$. 
Table 1. Clinical characteristics of the study sample used to validate the mRNA expression of kinesin family members $(n=208)$.

\begin{tabular}{|c|c|c|c|}
\hline \multirow{2}{*}{ Clinical Factors } & \multirow{2}{*}{ Group } & \multicolumn{2}{|c|}{ Patients } \\
\hline & & $n$ & $(\%)$ \\
\hline \multirow{2}{*}{ Sex } & Male & 93 & 45 \\
\hline & Female & 115 & 55 \\
\hline \multirow{2}{*}{ Age at 1st diagnosis (years) } & Median & \multirow{2}{*}{\multicolumn{2}{|c|}{$\begin{array}{c}59 \\
18-87\end{array}$}} \\
\hline & Range & & \\
\hline \multirow{3}{*}{ WHO Grade } & $\mathrm{WHO}^{\circ} \mathrm{I}$ & 61 & 29.3 \\
\hline & $\mathrm{WHO}^{\circ} \mathrm{II}$ & 88 & 42.3 \\
\hline & $\mathrm{WHO}^{\circ} \mathrm{III}$ & 59 & 28.4 \\
\hline \multirow{11}{*}{ Subtype } & Fibroblastic & 8 & 3.8 \\
\hline & Meningothelial & 9 & 4.3 \\
\hline & Transitional & 31 & 14.9 \\
\hline & Psammomatous & 4 & 1.9 \\
\hline & Angiomatous & 1 & 0.5 \\
\hline & Secretory & 3 & 1.4 \\
\hline & Atypical & 75 & 36.1 \\
\hline & Anaplastic & 40 & 19.2 \\
\hline & Rhabdoid & 2 & 1.0 \\
\hline & Papillary & 2 & 1.0 \\
\hline & Mixed/Unknown & 33 & 15.9 \\
\hline \multirow{6}{*}{ Location } & Convexity & 75 & 36.1 \\
\hline & Falx & 32 & 15.4 \\
\hline & Tentorial or parasagittal & 42 & 20.2 \\
\hline & Cranial base & 48 & 23.1 \\
\hline & Multiple & 4 & 1.9 \\
\hline & Other/NA & 7 & 3.4 \\
\hline \multirow{2}{*}{ Primary or recurrent tumor } & Primary tumor & 134 & 64 \\
\hline & Recurrent tumor & 74 & 36 \\
\hline \multirow{6}{*}{ Resection grade } & Simpson ${ }^{\circ} \mathrm{I}$ & 101 & 48.6 \\
\hline & Simpson ${ }^{\circ} \mathrm{II}$ & 59 & 28.4 \\
\hline & Simpson ${ }^{\circ} \mathrm{III}$ & 27 & 13 \\
\hline & Simpson ${ }^{\circ} \mathrm{IV}$ & 18 & 8.7 \\
\hline & Simpson ${ }^{\circ} \mathrm{V}$ & 1 & 0.5 \\
\hline & Unknown & 2 & 1.0 \\
\hline \multirow{2}{*}{ Postoperative treatment } & Radiotherapy & 62 & \\
\hline & Chemotherapy & 6 & \\
\hline
\end{tabular}

2.2. Subgroup Analysis Reveals Elevated KIF4A Levels in MGMs Experiencing Future Recurrence or Malignant Progression

Next, we were interested to find out if kinesin mRNA expression might predict the future clinical course of the disease in newly diagnosed primary tumors even within a given WHO grade. Since meningiomas tend to recur or even to progress to a higher grade, we divided our primary meningioma samples into tumors without future recurrence within the observed time interval (no recurrence NR, $\geq 60$ months), and clinically aggressive tumors reoccurring during our observation period (recurrence R) (Figure 1B; Table 2). There was a general trend for a higher expression of all kinesins studied in more aggressive tumors of the same WHO grade. However, significant differences were only observed for KIF4A between $2 \mathrm{NR}$ (WHO grade II, no recurrence) and the more aggressive $2 \mathrm{R}$ (WHO ${ }^{\circ} \mathrm{II}$, recurrence) tumors $(p=0.01)$. 
Table 2. Clinical characteristics of untreated primary meningioma patients used for the survival analyses $(n=106)$.

\begin{tabular}{|c|c|c|c|}
\hline \multirow{2}{*}{ Clinical Factors } & \multirow{2}{*}{ Group } & \multicolumn{2}{|c|}{ Patients } \\
\hline & & $n$ & $(\%)$ \\
\hline \multirow{2}{*}{ Sex } & Male & 39 & 36.8 \\
\hline & Female & 67 & 63.2 \\
\hline & Median & \multirow{2}{*}{\multicolumn{2}{|c|}{$\begin{array}{c}60 \\
24-85\end{array}$}} \\
\hline Age at 1st diagnosis (years) & Range & & \\
\hline \multirow{3}{*}{ WHO Grade } & $\mathrm{WHO}^{\circ} \mathrm{I}$ & 44 & 41.5 \\
\hline & $\mathrm{WHO}^{\circ} \mathrm{II}$ & 50 & 47.2 \\
\hline & $\mathrm{WHO}^{\circ} \mathrm{III}$ & 12 & 11.3 \\
\hline \multirow{11}{*}{ Subtype } & Fibroblastic & 7 & 6.6 \\
\hline & Meningothelial & 7 & 6.6 \\
\hline & Transitional & 20 & 18.9 \\
\hline & Psammomatous & 4 & 3.8 \\
\hline & Angiomatous & 0 & 0.0 \\
\hline & Secretory & 3 & 2.8 \\
\hline & Atypical & 42 & 39.6 \\
\hline & Anaplastic & 9 & 8.5 \\
\hline & Rhabdoid & 0 & 0.0 \\
\hline & Papillary & 1 & 0.9 \\
\hline & Mixed/Unknown & 13 & 12.3 \\
\hline \multirow{6}{*}{ Location } & Convexity & 38 & 35.8 \\
\hline & Falx & 16 & 15.1 \\
\hline & Tentorial or parasagittal & 22 & 20.8 \\
\hline & Cranial base & 25 & 23.6 \\
\hline & Multiple & 0 & 0.0 \\
\hline & Other/NA & 5 & 4.7 \\
\hline \multirow{2}{*}{ Primary or recurrent tumor } & Primary tumor & 106 & 100 \\
\hline & Recurrent tumor & 0 & 0 \\
\hline \multirow{3}{*}{ Resection grade } & Simpson ${ }^{\circ} \mathrm{I}$ & 59 & 55.7 \\
\hline & Simpson ${ }^{\circ} \mathrm{II}$ & 33 & 31.1 \\
\hline & Simpson ${ }^{\circ} \mathrm{III}$ & 14 & 13.2 \\
\hline \multirow{4}{*}{ Future clinical progression } & No future recurrence & 63 & \\
\hline & Recurrence with same $\mathrm{WHO}^{\circ}$ & 34 & \\
\hline & Recurrence with higher $\mathrm{WHO}^{\circ}$ & 9 & \\
\hline & & \multicolumn{2}{|c|}{ Median } \\
\hline \multirow{3}{*}{ Follow-up time (months) } & $\mathrm{WHO}^{\circ} \mathrm{I}$ & \multicolumn{2}{|c|}{135.5} \\
\hline & $\mathrm{WHO}^{\circ} \mathrm{II}$ & \multicolumn{2}{|c|}{100.1} \\
\hline & $\mathrm{WHO}^{\circ} \mathrm{III}$ & \multicolumn{2}{|c|}{47.9} \\
\hline
\end{tabular}

\subsection{WHO Grade-Specific Increase of Kinesin Protein Levels in Meningioma Tissue Samples}

To learn more about the tissue distribution of kinesin expression on a cellular level, we studied the protein expression in meningioma tissues by immunohistochemistry (Figure 2). Therefore, we used ten meningioma tissue samples for each WHO grade and stained them for KIFC1, KIF4A, KIF11, KIF14 and KIF20A. Patient data are depicted in Supplementary Table S2. Staining was evaluated as percent positive cells in five categories $(<1 \%, 1-5 \%,>5 \%,>20 \%$ and $>50 \%)$. Staining results are illustrated in Figure 2.

In general, we observed a heterogeneous predominantly perinuclear staining pattern for all kinesin members. For instance, $60 \%$ of $\mathrm{WHO}^{\circ} \mathrm{I}$ tumors showed less than $1 \%$ of KIFC1-positive cells, while in the remaining tumors up to $5 \%$ of cells were stained. In contrast, in $\mathrm{WHO}^{\circ} \mathrm{II}$ tumors most of the samples were positive for KIFC1 in up to $20 \%$ with a further increase in the majority of $\mathrm{WHO}^{\circ} \mathrm{III}$ tumors. Regarding KIF4A and KIF11, we made similar observations, though the number of meningiomas with more than $50 \%$ kinesin-expressing cells further increased in $\mathrm{WHO}^{\circ} \mathrm{II}$ and ${ }^{\circ} \mathrm{III}$ tumors. In contrast, 
protein expression of KIF14 did not seem to vary according to the WHO grade, while for KIF20A, a WHO grade-dependent increased expression was visible again.

A
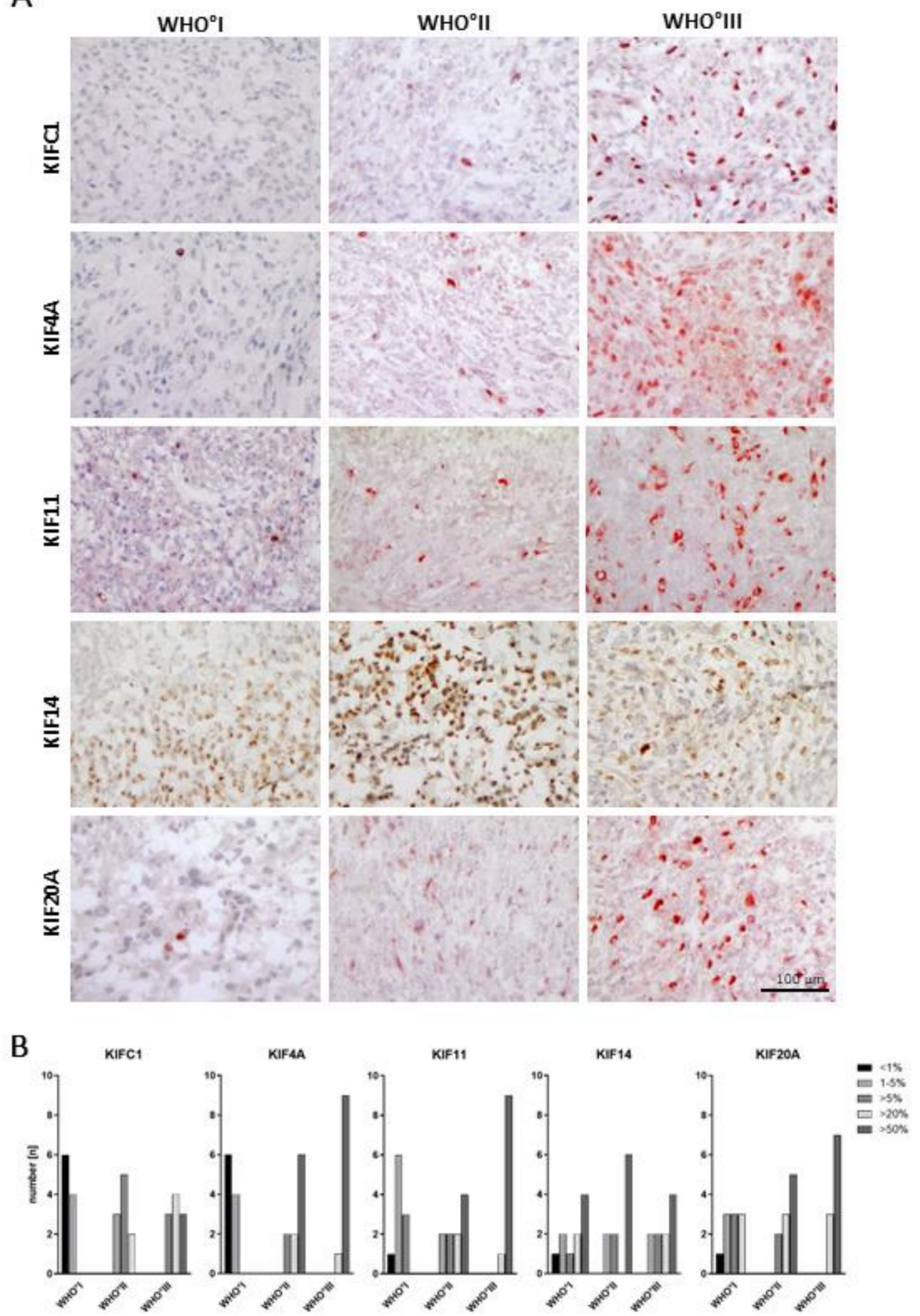

Figure 2. Immunohistochemical staining of meningioma tissue samples reveals a WHO grade-specific increase of protein levels. (A) Representative immunohistochemical stainings are shown for KIFC1, KIF4A, KIF14 and KIF20A and each WHO grade. Ten meningioma tissue samples of each WHO grade were stained with antibodies against KIFC1, KIF4A, KIF11, KIF14, or KIF20A. (B) Staining was evaluated as percent positive cells in five categories $(<1 \%, 1-5 \%,>5 \%,>20 \%$ and $>50 \%$ positive cells). 
In summary, except for KIF14, all kinesins analyzed showed an increment in the number of positive cells with increasing WHO grade, which was most pronounced for KIF4A and KIF11. Thus, we could confirm that the observed differential mRNA expression translates to a differential protein expression for most of the kinesin family members tested.

\subsection{High Levels of KIFC1, KIF11, KIF14 and KIF20A Are Associated with Shorter Progression-Free Survival}

Next, we explored if mRNA expression levels of kinesin genes are associated with clinical outcome. To avoid a survival bias due to incomplete tumor resection or treatment-induced expression changes in recurrent tumors, only patients who underwent a gross total tumor resection (Simpson $\left.{ }^{\circ} \mathrm{I}-\mathrm{III}\right)$, a minimal follow-up time of 60 months, and without any prior treatment were included $(n=106)$ (Table 2). MicroRNA expression was divided by the median in a low and high expression group to assess progression-free survival of patients in these two groups as illustrated by Kaplan-Meier plots (Figure 3).
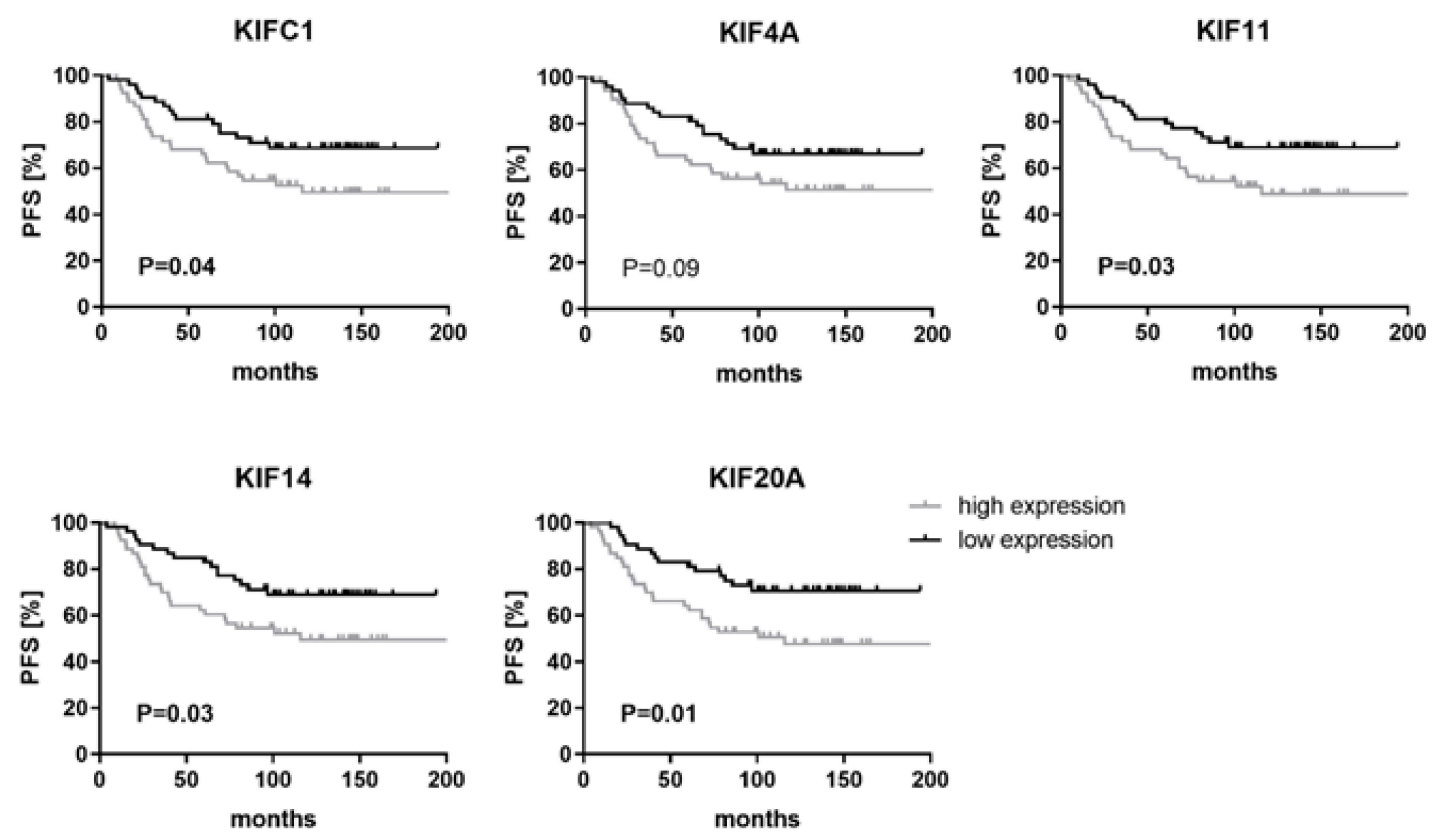

Figure 3. High mRNA expression levels of KIFC1, KIF11, KIF14 and KIF20A are associated with shorter progression-free survival. Kaplan-Meier plots show survival association of each investigated kinesin. The patients were categorized into two groups according to their median mRNA expression levels into high (grey curve) and low (black curve) expression. Only primary tumor samples and Simpson ${ }^{\circ} \mathrm{I}-\mathrm{III}$ resected tumors were included in this analysis $(n=106)$. Prognostic significance was determined using Log-rank (Mantel-Cox) tests. PFS: Progression-free survival.

This analysis revealed that high levels of KIFC1 ( $p=0.04 ; \operatorname{HR} 1.84), \operatorname{KIF11}(p=0.03 ; \operatorname{HR} 1.88)$, $\operatorname{KIF14}(p=0.03$; HR 1.91) and KIF20A ( $p=0.01 ;$ HR 2.13) were associated with a shorter progression-free survival, suggesting kinesins as novel prognostic factors in meningiomas.

\subsection{NCH93 as a Novel Anaplastic Meningioma Cell Line for Functional Testing}

Due to a paucity of well-growing human in vitro and in vivo meningioma models, we established the novel meningioma cell line NCH93. Cell culture was established from a human anaplastic meningioma as described [38] (Figure 4A). 
A
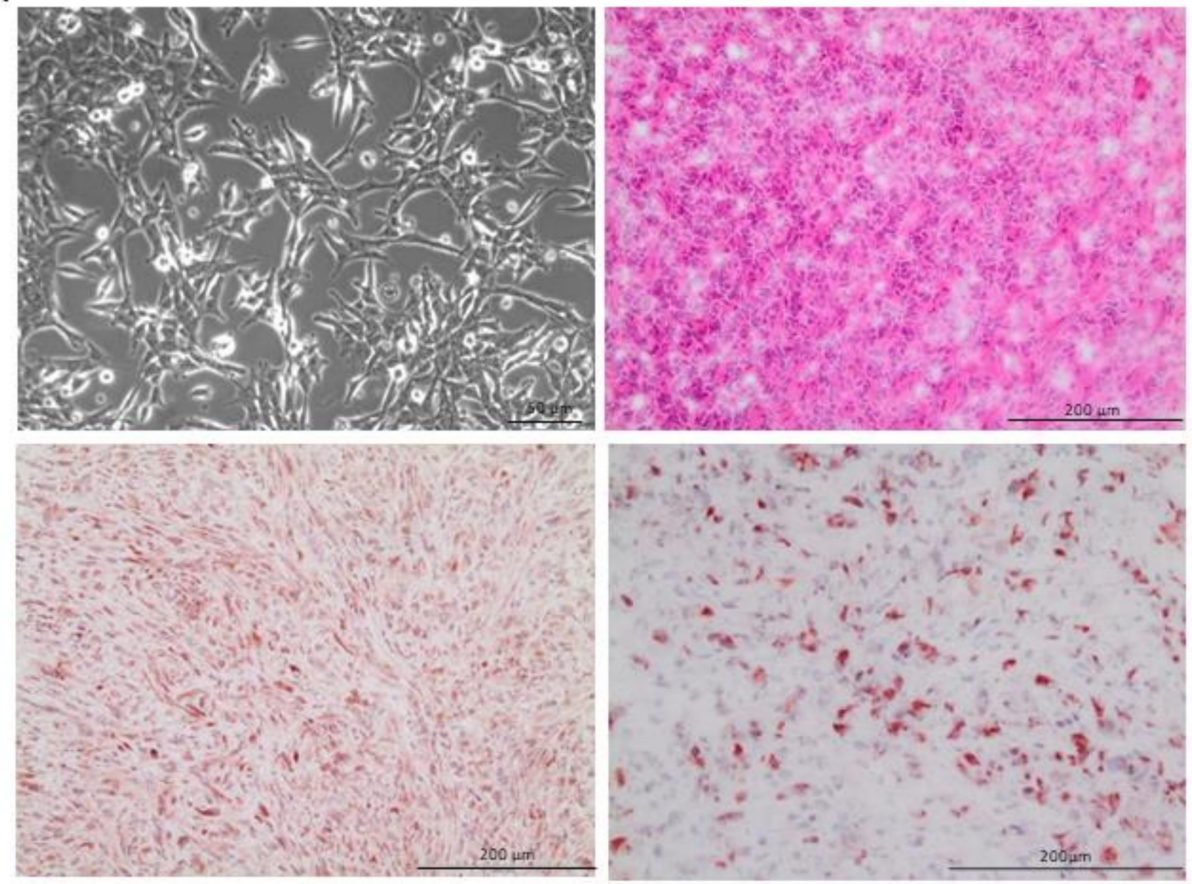

$\mathrm{B}$
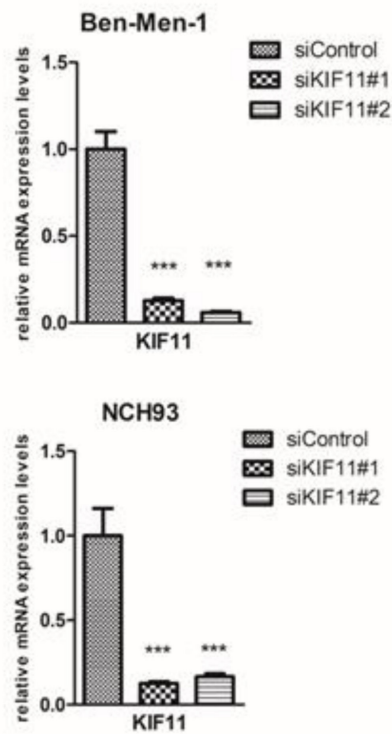

C

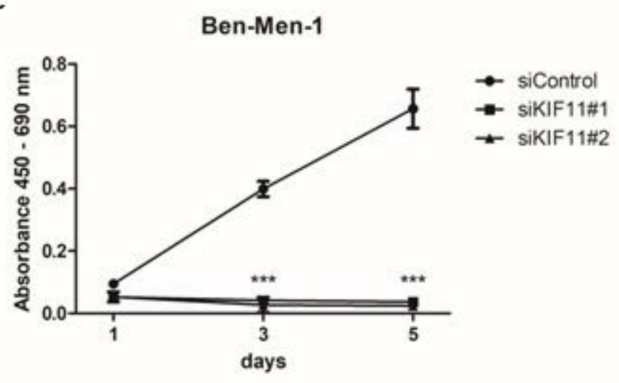

$\mathrm{NCH} 93$

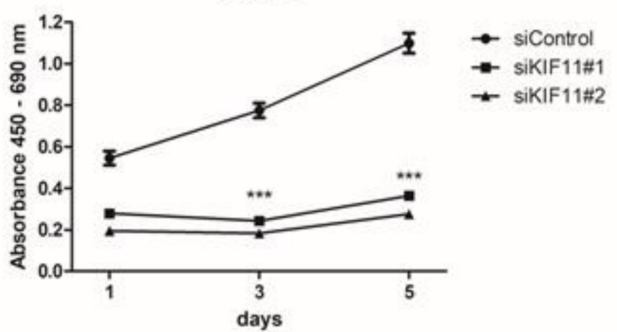

Figure 4. siRNA-mediated knockdown of KIF11 reduces the proliferation of Ben-Men-1 cells and the human anaplastic meningioma cell line NCH93. (A, left upper corner) Representative light microscopy images of adherently growing NCH93 cells. (A, right upper corner) Representative H\&E staining of $\mathrm{NCH} 93$ tumors grown in the flanks of mice. (A, left and right bottom corners) Immunohistochemical staining for EMA and Ki67, respectively. (B) Transfection of Ben-Men-1 and NCH93 cells with 25 nM corresponding siRNAs overnight. Knockdown efficiency was evaluated by qRT-PCR and data were normalized to the siRNA of the control sample. (C) BrdU proliferation assay was performed on day 1 , day 3 and day 5 after seeding. Error bars indicate SEM. Significance levels: ${ }^{* *} p<0.001$.

To confirm their tumorigenicity, $10^{6} \mathrm{NCH} 93$ cells embedded in Matrigel were injected in the flanks of 5-6 week-old female NMRI/nu mice. Five out of six tumors reached a size of approximately $200 \mathrm{~mm}^{3}$ five weeks after implantation, and after two additional weeks, the mice were sacrificed reaching a tumor volume of approximately $1000 \mathrm{~mm}^{3}$. To further characterize the cell line, we performed a targeted 
panel sequencing. This panel contained 130 genes frequently mutated in brain tumors including MGMs. Sequencing revealed a deleterious NF2 frameshift deletion (p.D130fs, p.D172fs, p.D213fs) and pathogenic missense mutation in the genes ALK (p.K1491R) and PTCH1 (p.P1164L) according to COSMIC data (https://cancer.sanger.ac.uk/cosmic/browse/genome) (Supplementary Table S4). Excised tumors were immunohistochemically stained for the meningioma marker EMA and the proliferation marker Ki67. NCH93 tumor tissue exhibited a strong staining for EMA and a substantial number of about $50 \%$ of cells stained positively for Ki67, which is in concordance with its fast-paced in vivo tumor growth.

\subsection{Depletion of KIF11 via siRNA Inhibits Meningioma Proliferation In Vitro}

To finally address the question, if differentially expressed kinesin family members have an impact on tumor cell proliferation of meningioma cells, we performed a siRNA-mediated knockdown of KIFC1, KIF4A, KIF11, KIF14 and KIF20A. To this end, we transfected the benign meningioma cell line Ben-Men-1 and the anaplastic meningioma cell line NCH93 with two different siRNAs targeting each kinesin and a negative control siRNA and analyzed the proliferative activity by the BrdU assay at different points of time. siRNA-mediated knockdown resulted in $>70 \%$ knockdown on the mRNA level of all targeted genes as validated by qRT-PCR (Figure 4B; Supplementary Figure S1). Subsequent BrdU incorporation assay revealed a significant decrease in tumor cell proliferation in KIF11-depleted Ben-Men-1 and NCH93 cells for both siRNAs employed (Figure 4C). Cell proliferation was inhibited by siRNA against KIF11 in the benign cell line Ben-Men- 1 by $91 \%$ and $95 \%$ on day 3 and $5(p<0.001)$ and by $56 \%, 72 \%$ and $71 \%$ on day 1,3 and 5 in the malignant cell line NCH93 $(p<0.001)$, respectively. Moreover, knockdown of KIF4A also resulted in reduced cell proliferation $(p<0.001)$ of Ben-Men-1 cells, but not of NCH93 cells. Knockdown of other kinesins failed to affect tumor cell proliferation in any of the cell lines (Supplementary Figure S2). In summary, these data support an important functional role of KIF11 for meningioma growth and its use as a novel therapeutic target in clinically aggressive meningiomas.

\section{Discussion}

Clinically aggressive meningiomas are still challenging due to the lack of therapy options despite surgery and radiotherapy [8]. Since effective chemotherapeutic agents are still missing, the identification of novel treatment approaches is urgently needed. To query if kinesin family members might represent novel molecular therapeutic targets, we re-analyzed our previous microarray data set of benign, atypical and anaplastic meningiomas and identified five differentially expressed kinesins (KIFC1, KIF4A, KIF11, KIF14 and KIF20A). This is of major interest because kinesins play an important role in many physiological processes including intracellular vesicle transport and mitosis and are upregulated in many different cancer types [18,39]. Further validation in an extended study sample of 208 cases fairly representing all WHO grades revealed a significant upregulation of all investigated kinesins in meningiomas $\mathrm{WHO}^{\circ} \mathrm{I}$ to ${ }^{\circ} \mathrm{III}$ which even translated into an upregulated protein expression. As a further indication for the importance of kinesin family members for meningioma growth, we found that high mRNA expression levels of almost all kinesins were associated with shorter progression-free survival. To further elaborate on the functional role of kinesins, we performed knockdown experiments on Ben-Men-1 cells and the newly developed anaplastic meningioma cell line NCH93. This resulted in a significantly inhibited tumor cell proliferation of KIF11-depleted cells by up to $95 \%$ and $71 \%$, respectively, suggesting KIF11 as a promising novel therapeutic target in meningiomas.

KIF11's functions can be divided into mitosis-related and non-mitosis-related properties. The gene is essential to assemble the mitotic spindle, and its loss leads to a monopolar spindle phenotype due to the failure of centrosome separation, resulting in a radial array of microtubules with the chromosomes distributed along the circumference. This causes a G2/M arrest, which may induce apoptosis [24,40]. Non-mitosis-related functions of KIF11 include neuronal growth cone extension, navigation, and migration [41]. Our demonstration that KIF11 mRNA and protein levels increased with 
meningioma WHO grade and that higher mRNA levels of KIF11 were related to shorter progression-free survival, is consistent with prior literature reports in other cancer types [24,42-46]. Although all kinesins resulted in a WHO grade-dependent upregulation, only the knockdown of KIF11 with two different siRNAs targeting KIF11 led to an inhibited proliferation of the benign meningioma cell line Ben-Men-1 and the anaplastic $\mathrm{NCH} 93$ cell line in vitro, indicating a pivotal role in tumorigenesis and the sustained growth of meningiomas. Interestingly, several selective small molecule inhibitors have been developed and pre- and clinically tested with promising results in other tumors types, suggesting their future analysis in meningiomas [47-58].

KIFC1 plays an important physiological role in the vesicular and organelle trafficking, spermiogenesis and oocyte development [59-63]. Furthermore, KIFC1 is widely expressed in cancer cells and may be essential for the bi-multipolar mitotic division of cancer cells but is dispensable in ordinary somatic cells, which qualifies KIFC1 as an excellent target in cancer therapy [29,64-70]. Direct KIFC1 inhibitors including AZ82, CW069 and transcription inhibitor PJ34 are readily available and have shown promising results in vitro and in vivo [68]. We demonstrated that KIFC1 mRNA and protein expression increased in meningiomas with the WHO grade. However, although progression-free survival was related to the expression of KIFC1 mRNA, the knockdown of KIFC1 in two different meningioma cell lines did not show any effect on proliferation, indicating KIFC1 as a dispensable gene for meningioma proliferation which might be due to the upregulation of currently unknown compensatory genes [29,65,67-72].

KIF4A, KIF14 and KIF20A are shown to be overexpressed across many human cancer types suggesting a link between expression levels and overall survival. Furthermore, their knockdown inhibited proliferation and migration in breast, prostate, lung, ovarian and gastric tumors [73-85]. In meningiomas, however, KIF20A demonstrated an effect on progression-free survival but failed to show a significant functional impact on cell proliferation in vitro. KIF4A showed a differential protein and mRNA expression and discrimination of non-recurrent $\mathrm{WHO}^{\circ} \mathrm{II}$ meningiomas vs. clinically aggressive tumors of the same grade. In addition, high mRNA levels of KIF4A showed a trend towards a poorer progression-free survival $(p=0.09)$ and upon knockdown, reduced the proliferation of Ben-Men-1 cells. Accordingly, KIF4A could still serve as a target in meningiomas and deserves further investigation. However, small molecule inhibitors are currently not available. Last but not least as for KIF14, despite differential protein and mRNA expression in meningiomas, progression-free survival or proliferation in vitro seemed to be unaffected by KIF14. Thus, as compared to the strong effects seen for other kinesin family members, KIF14 may play a minor role in meningioma pathogenesis.

Finally, appropriate meningioma in vitro and in vivo models are rare. The Ben-Men-1 cell line was established from a benign meningioma, which has been genetically modified by retrovirally introducing the hTERT gene and exhibits an unusual high proliferation rate for a $\mathrm{WHO}^{\circ} \mathrm{I}$ meningioma [86]. If at all, it exhibits only a slow growth rate in vivo [86,87]. Other cell lines are less commonly used or are quite old [87]. This forced us to establish a novel anaplastic meningioma cell line, which shows unlimited growth in vitro and after xenotransplantation forms tumors within 5-6 weeks in the flank of NMRI/nu mice. Panel sequencing of targeted genes revealed a deleterious NF2 frameshift mutation and pathogenic PTCH1 and ALK mutations. Therefore, this novel cell line might accelerate meningioma research by providing a platform for functional in vitro and in vivo experiments.

Altogether, in this study, we were able to characterize the prognostic and functional role of several kinesin family members of which KIF11 provided the most promising properties as a novel prognostic marker and therapeutic target, which may offer new treatment options for aggressive meningiomas.

\section{Materials and Methods}

\subsection{Tumor Samples and RNA Isolation}

Patients and corresponding tumors were included as part of the FORAMEN effort of the Neuro-Oncology Section of the German Society of Neurosurgery (DGNC) [37]. FORAMEN aims at 
conducting clinical and translational projects on aggressive meningiomas. The study was approved by the institutional review board at Heidelberg Medical Faculty (Ethical code: S-005/2003, permission date: 31 March 2003). Informed consent was received from all patients. Fresh tumor material obtained intraoperatively was snap-frozen and stored at $-80{ }^{\circ} \mathrm{C}$ until further processing. Only samples with a vital tumor cell content $>60 \%$ as determined on H\&E-stained slides from each tissue by a board-certified neuropathologist were eligible (Department of Neuropathology, University Hospital Heidelberg, Germany). Total RNA was extracted from tissues using the AllPrep Kit (Qiagen) according to the manufacturer's instructions. RNA integrity was assessed by the Agilent 2100 Bioanalyzer. RNA was quantified by NanoDrop ND-1000 spectrophotometer (Thermo-Scientific, Waltham, MA, USA), and then stored at $-80^{\circ} \mathrm{C}$ until further analysis.

\subsection{Quantitative Real-Time PCR}

Equal amounts of total RNA $(1 \mu \mathrm{g})$ were reverse-transcribed using the Transcriptor First Strand cDNA Synthesis Kit (Roche, Basel, Switzerland) with random hexamer primers for one hour at $50^{\circ} \mathrm{C}$. qPCR was performed in triplicates on a LightCycler 480 (Roche) using the LightCycler 480 Probes Master and probes from the Universal Probe Library (Roche) as described (www.roche-applied-science.com). Relative fold changes between the expression of target genes were calculated by using the $2^{\wedge}-\Delta \Delta C q$ method. GAPDH and ACTB were used as reference genes. The relative expression levels of KIFC1, KIF4A, KIF11, KIF14A and KIF20A mRNA levels were normalized to the mean of the meningioma $\mathrm{WHO}^{\circ} \mathrm{I}$ samples. The primers used are shown in Supplementary Table S1.

\subsection{Immunohistochemical Staining}

Thirty tissue samples of meningioma patients were used $\left(\mathrm{WHO}^{\circ} \mathrm{I} n=10, \mathrm{WHO}^{\circ} \mathrm{II} n=10\right.$, $\mathrm{WHO}^{\circ} \mathrm{III} n=10$, Supplementary Table S2). Stainings were performed on acetone-fixed cryosections $(5-7 \mu \mathrm{m})$. Antibodies and dilutions used were as follows: anti-KIFC1 (rabbit monoclonal IgG, ab172620, Abcam, Cambridge, UK) 1:100, anti-KIF4A (rabbit polyclonal IgG, ab122227, Abcam) 1:400, anti-Eg5/KIF11 (rabbit polyclonal IgG, ab37814, Abcam) 1:1000, anti-KIF14 (rabbit polyclonal IgG, ab71155, Abcam) 1:250 (using UltraVision Quanto Detection Kit HRP, Thermo Scientific, Waltham, MA, USA), and anti-KIF20A (rabbit polyclonal IgG, ab85644, Abcam) 1:400. Primary antibodies were diluted with DAKO diluent (Agilent, Santa Clara, CA, USA) in the above-mentioned concentrations and then stained for $60 \mathrm{~min}$ at room temperature (RT) covered from light. Slides were then washed three times with PBS-T (0.05\%). Next, secondary antibody (anti-rabbit, PK-6101, Vectastain, Vector labs, Burlingame, CA, USA) diluted in serum and DPBS (ThermoFisher Scientific) were added to the slides and incubated for $30 \mathrm{~min}$. Then the slides were incubated with an avidin-biotin-complex (PK-6101, Vectastain, Vector labs) for $30 \mathrm{~min}$, followed by a PBS wash and an AEC substrate incubation. The slides were then rinsed with distilled water for five min and counterstained with hematoxylin. Four pictures of each slide were taken (three pictures at $20 \times$ and one at 10× magnification) and two independent observers evaluated each tissue sample according to the following categories: $<1 \%, 1-5 \%,>5 \%,>20 \%$ and $>50 \%$ positive cells. Rabbit IgGs served as a negative control (anti-rabbit, PK-6101, Vectastain, Vector labs). NCH93 tumor samples excised from mice were stained accordingly following the same protocol as mentioned above. Antibodies and dilutions for NCH93 tumor staining were used as follows: anti-EMA (rabbit monoclonal IgG, ab136615, Abcam) 1:50 and anti-Ki67 (rabbit monoclonal IgG, ab15580, Abcam) 1:50.

\subsection{Cell Lines}

NCH93 tumor cells originated from a 64-year-old man suffering from a relapsed anaplastic meningioma ( $\left.\mathrm{WHO}^{\circ} \mathrm{III}\right)$ located in the left parieto-occipital region. The tumor sample was first mechanically dissected. Then the resulting cell suspension was cultured in Dulbecco's minimal Eagle's medium supplemented with 10\% fetal calf serum (Sigma-Aldrich, St. Louis, MO, USA), 2\% L-GlutaMAX (Sigma-Aldrich) and 1\% Penicillin/Streptomycin (Sigma-Aldrich). Cells were subcultured in a ratio of 
1:10 twice a week. Mycoplasma contamination was excluded by 4',6-diamidino-2-phenylindole staining (Roche). The benign cell line Ben-Men-1 was purchased from DSMZ (Braunschweig, Germany). Cells were grown in the same medium as $\mathrm{NCH} 93$, and both were cultured at $37^{\circ} \mathrm{C}$ in a humidified environment in a $5 \% \mathrm{CO}_{2}$ atmosphere. Cell lines were authenticated by STR DNA profiling analysis (Leibniz Institute DMSZ, Braunschweig, Germany).

\subsection{Panel Sequencing}

NCH93 cells were profiled by targeted panel sequencing to identify meningioma-typical aberrations. The panel contained 130 genes reported to be frequently mutated in brain tumors including MGMs as described previously [88]. Sequencing was done by applying a custom hybrid capture approach (Agilent Technologies, CA, USA) on a NextSeq500 instrument (Illumina, San Diego, CA, USA). For single nucleotide variants and InDel calling, SAMtools mpileup and Platypus were utilized. The panel was designed to assess the frequency of known brain tumor mutations rather than novel mutational events.

\section{6. siRNA-Mediated Knockdown}

In brief, meningioma cells were transfected with siRNA against KIFC1 (s7906, s7907, Invitrogen, Carlsbad, CA, USA), KIF4A (s24407, s24408, Invitrogen), KIF11 (s7902, s7903, Invitrogen), KIF14 (s19263, s19265, Invitrogen) and KIF20A (s19676, s19677, Invitrogen) or siRNA negative control (Cat. \# 4390843, Invitrogen). Lipofectamine RNAiMAX reagent (Cat. \# 13778030, Invitrogen) was used to deliver siRNAs into the cells. Cells were transfected with a final concentration of $25 \mathrm{nM}$ siRNA and $7.5 \mu \mathrm{L}$ Lipofectamine RNAiMAX in $1 \mathrm{~mL}$ OptiMEM (Gibco) overnight. On the next day, the medium was changed to DMEM supplemented with 10\% FCS, 2\% GlutaMAX (Gibco), and 1\% Pen/Strep and cells were further used for experiments. Validation of the knockdown was assessed by qRT-PCR. A decrease in mRNA levels of $>70 \%$ compared to siRNA negative control was used as a threshold for a successful siRNA-mediated knockdown of the target gene.

\subsection{Cell Proliferation Assay}

Cell proliferation was quantified using the Cell Proliferation ELISA, BrdU Kit (). NCH93 and Ben-Men-1 cells were cultured in 6-well plates at a density of $3 \times 10^{5}$ cells/well and transfected as described above. The day after, cells were harvested and counted, and 5000 cells were seeded in 96-well plates in $100 \mu \mathrm{L}$ medium. On day 1, 3 and 5, $10 \mu \mathrm{L}$ BrdU labeling solution was added to the cells (final concentration of $10 \mu \mathrm{M} \mathrm{BrdU}$ ) and incubated for two hours. Next, the medium was removed from the cells by tapping off. Cells were fixed with $200 \mu \mathrm{L}$ per well FixDenat and incubated for an additional $30 \mathrm{~min}$ at RT. FixDenat was removed by tapping off and $100 \mu \mathrm{L}$ anti-BrdU-POD working solution per well was added and incubated for $90 \mathrm{~min}$ at RT. The antibody conjugate was removed and wells were rinsed three times with $200 \mu \mathrm{L}$ PBS. Thereafter, $100 \mu \mathrm{L}$ substrate solution was added and incubated for an additional $10 \mathrm{~min}$ at RT. Then absorbance was measured at $450 \mathrm{~nm}$ and reference wavelength $690 \mathrm{~nm}$ by Microplate Reader Tecan Infinite PRO.

\subsection{Xenograft Mouse Model}

To further characterize the $\mathrm{NCH} 93$ cells, their tumorigenicity was tested in a xenograft mouse model. Animal experiments were approved by the Regierungspraesidium Karlsruhe (35-9185.81/G-193/17). For the in vivo tumorigenicity study, $1 \times 10^{6}$ cells suspended in $100 \mu \mathrm{L}$ Matrigel (Cat. \# 356237, Corning, New York, NY, USA) were injected subcutaneously into the flank regions of 5-6 week-old female NMRI/nu mice (Janvier Laboratory, Le Genest-Saint-Isle, France). Tumor growth was measured every second day by a caliper. Animals were sacrificed seven weeks after tumor cell injection reaching a tumor volume of approximately $1000 \mathrm{~mm}^{3}$. 


\subsection{Statistical Analysis}

All measurements were performed in triplicates. Values are expressed as mean $\pm \mathrm{SEM} ; p$-values were calculated using two-tailed Student's t-test in GraphPad Prism (Version 8.0.1, GraphPad, San Diego, CA, USA). For survival analysis, progression-free survival (PFS) was used as an end-point. Progression was assessed in MRI scans. Prognostic significance was determined using the Log-rank tests. $p$-values $<0.05$ were considered significant $\left({ }^{*} p<0.05 ;{ }^{* *} p<0.01 ; * * * p<0.001\right)$.

\section{Conclusions}

In a large set of benign, atypical and anaplastic meningiomas, several kinesin family members have been discovered as prognostic factors. Among them, knockdown experiments identified KIF11 as the most promising therapeutic target. Finally, by establishing and characterizing the NF2-mutated anaplastic meningioma cell line $\mathrm{NCH} 93$, we provide a novel powerful cell model for meningioma research. This may help to improve the treatment of aggressive meningiomas.

Supplementary Materials: The following are available online at http://www.mdpi.com/2072-6694/11/4/545/s1, Figure S1: Efficiency of siRNA-mediated knockdown evaluated by qRT-PCR, Figure S2: Knockdown of KIFC1, KIF4A, KIF14 and KIF20A failed to show a robust effect in both meningioma cell lines, Table S1: Primer sequences, Table S2: Clinical data of meningiomas employed for protein expression analysis $(n=30)$, Table S3: Comparative expression of kinesin family members in a published microarray dataset, Table S4: Panel Sequencing data of NCH93 cells.

Author Contributions: Conceptualization, G.J. and C.H.-M.; methodology, G.J., C.H.-M.; software, G.J., R.W., T.Y., F.S.; validation, G.J., T.Y., C.R., S.D. and F.S.; formal analysis, G.J.; investigation, G.J., T.Y., C.R., S.D., R.W., F.S.; resources, C.H.-M., A.U., A.v.D., K.Z., M.M., J.D., A.A., K.L., M.W., C.S., F.S., A.F.K., R.K., M.S.; writing一original draft preparation, G.J.; writing—review and editing, C.H.M.; visualization, G.J., T.Y.; supervision, C.H.-M.; project administration, G.J., C.H.-M.; funding acquisition, G.J., C.H.M.

Funding: This study has been funded by a grant from the Stiftung fuer Krebs-und Scharlachforschung Mannheim (G.J.) and the German Cancer Aid (R.W., C.H.M.)

Acknowledgments: We greatly appreciate the technical assistance of Farzaneh Kashfi, Melanie Greibich, Mandy Barthel, Ilka Hearn and Axel Schöffel.

Conflicts of Interest: The authors declare no conflict of interest.

\section{References}

1. Mawrin, C.; Perry, A. Pathological classification and molecular genetics of meningiomas. J. Neurooncol. 2010, 99, 379-391. [CrossRef]

2. Louis, D.N.; Ohgaki, H.; Wiestler, O.D.; Cavenee, W.K.; Burger, P.C.; Jouvet, A.; Scheithauer, B.W.; Kleihues, P. The 2007 WHO classification of tumours of the central nervous system. Acta Neuropathol. 2007, 114, 97-109. [CrossRef]

3. Baldi, I.; Engelhardt, J.; Bonnet, C.; Bauchet, L.; Berteaud, E.; Gruber, A.; Loiseau, H. Epidemiology of meningiomas. Neurochirurgie 2014. [CrossRef] [PubMed]

4. Van Alkemade, H.; de Leau, M.; Dieleman, E.M.; Kardaun, J.W.; van Os, R.; Vandertop, W.P.; van Furth, W.R.; Stalpers, L.J. Impaired survival and long-term neurological problems in benign meningioma. Neuro Oncol. 2012, 14, 658-666. [CrossRef] [PubMed]

5. Durand, A.; Labrousse, F.; Jouvet, A.; Bauchet, L.; Kalamarides, M.; Menei, P.; Deruty, R.; Moreau, J.J.; Fevre-Montange, M.; Guyotat, J. WHO grade II and III meningiomas: A study of prognostic factors. J. Neuro Oncol. 2009, 95, 367-375. [CrossRef] [PubMed]

6. Vranic, A.; Popovic, M.; Cor, A.; Prestor, B.; Pizem, J. Mitotic count, brain invasion, and location are independent predictors of recurrence-free survival in primary atypical and malignant meningiomas: A study of 86 patients. Neurosurgery 2010, 67, 1124-1132. [CrossRef]

7. Gousias, K.; Schramm, J.; Simon, M. The Simpson grading revisited: Aggressive surgery and its place in modern meningioma management. J. Neurosurg. 2016, 125, 551-560. [CrossRef] [PubMed]

8. Alexiou, G.A.; Gogou, P.; Markoula, S.; Kyritsis, A.P. Management of meningiomas. Clin. Neurol Neurosurg. 2010, 112, 177-182. [CrossRef] [PubMed] 
9. Clark, V.E.; Erson-Omay, E.Z.; Serin, A.; Yin, J.; Cotney, J.; Ozduman, K.; Avsar, T.; Li, J.; Murray, P.B.; Henegariu, O.; Yilmaz, S.; et al. Genomic analysis of non-NF2 meningiomas reveals mutations in TRAF7, KLF4, AKT1, and SMO. Science 2013, 339, 1077-1080. [CrossRef] [PubMed]

10. Clark, V.E.; Harmanci, A.S.; Bai, H.; Youngblood, M.W.; Lee, T.I.; Baranoski, J.F.; Ercan-Sencicek, A.G.; Abraham, B.J.; Weintraub, A.S.; Hnisz, D.; et al. Recurrent somatic mutations in POLR2A define a distinct subset of meningiomas. Nat. Genet. 2016, 48, 1253-1259. [CrossRef] [PubMed]

11. Abedalthagafi, M.; Bi, W.L.; Aizer, A.A.; Merrill, P.H.; Brewster, R.; Agarwalla, P.K.; Listewnik, M.L.; Dias-Santagata, D.; Thorner, A.R.; Van Hummelen, P.; et al. Oncogenic PI3K mutations are as common as AKT1 and SMO mutations in meningioma. Neuro Oncol. 2016, 18, 649-655. [CrossRef] [PubMed]

12. Brastianos, P.K.; Horowitz, P.M.; Santagata, S.; Jones, R.T.; McKenna, A.; Getz, G.; Ligon, K.L.; Palescandolo, E.; Van Hummelen, P.; Ducar, M.D.; et al. Genomic sequencing of meningiomas identifies oncogenic SMO and AKT1 mutations. Nat. Genet. 2013, 45, 285-289. [CrossRef] [PubMed]

13. Sahm, F.; Schrimpf, D.; Olar, A.; Koelsche, C.; Reuss, D.; Bissel, J.; Kratz, A.; Capper, D.; Schefzyk, S.; Hielscher, T.; et al. TERT promoter mutations and risk of recurrence in meningioma. J. Natl. Cancer Inst. 2016, 108. [CrossRef] [PubMed]

14. Reuss, D.E.; Piro, R.M.; Jones, D.T.; Simon, M.; Ketter, R.; Kool, M.; Becker, A.; Sahm, F.; Pusch, S.; Meyer, J.; et al. Secretory meningiomas are defined by combined KLF4 K409Q and TRAF7 mutations. Acta Neuropathol. 2013, 125, 351-358. [CrossRef] [PubMed]

15. Pachow, D.; Andrae, N.; Kliese, N.; Angenstein, F.; Stork, O.; Wilisch-Neumann, A.; Kirches, E.; Mawrin, C. mTORC1 inhibitors suppress meningioma growth in mouse models. Clin. Cancer Res. 2013, 19, 1180-1189. [CrossRef] [PubMed]

16. Gogineni, V.R.; Nalla, A.K.; Gupta, R.; Gujrati, M.; Klopfenstein, J.D.; Mohanam, S.; Rao, J.S. alpha3beta1 integrin promotes radiation-induced migration of meningioma cells. Int. J. Oncol. 2011, 38, 1615-1624. [CrossRef] [PubMed]

17. Weller, M.; Roth, P.; Sahm, F.; Burghardt, I.; Schuknecht, B.; Rushing, E.J.; Regli, L.; Lindemann, J.P.; von Deimling, A. Durable control of metastatic AKT1-mutant WHO Grade 1 meningothelial meningioma by the AKT inhibitor, AZD5363. J. Natl. Cancer Inst. 2017, 109, 1-4. [CrossRef]

18. Hirokawa, N.; Tanaka, Y. Kinesin superfamily proteins (KIFs): Various functions and their relevance for important phenomena in life and diseases. Exp. Cell Res. 2015, 334, 16-25. [CrossRef]

19. Miki, H.; Setou, M.; Hirokawa, N.; Group, R.G.; Members, G.S.L. Kinesin superfamily proteins (KIFs) in the mouse transcriptome. Genome Res. 2003, 13, 1455-1465. [CrossRef]

20. Lawrence, C.J.; Dawe, R.K.; Christie, K.R.; Cleveland, D.W.; Dawson, S.C.; Endow, S.A.; Goldstein, L.S.; Goodson, H.V.; Hirokawa, N.; Howard, J.; et al. A standardized kinesin nomenclature. J. Cell Biol. 2004, 167, 19-22. [CrossRef]

21. Vale, R.D.; Reese, T.S.; Sheetz, M.P. Identification of a novel force-generating protein, kinesin, involved in microtubule-based motility. Cell 1985, 42, 39-50. [CrossRef]

22. Wordeman, L. How kinesin motor proteins drive mitotic spindle function: Lessons from molecular assays. Semin. Cell Dev. Biol. 2010, 21, 260-268. [CrossRef] [PubMed]

23. Hirokawa, N. Kinesin and dynein superfamily proteins and the mechanism of organelle transport. Science 1998, 279, 519-526. [CrossRef]

24. Venere, M.; Horbinski, C.; Crish, J.F.; Jin, X.; Vasanji, A.; Major, J.; Burrows, A.C.; Chang, C.; Prokop, J.; $\mathrm{Wu}, \mathrm{Q}$; et al. The mitotic kinesin KIF11 is a driver of invasion, proliferation, and self-renewal in glioblastoma. Sci. Transl. Med. 2015, 7, 304ra143. [CrossRef] [PubMed]

25. Liu, X.; Gong, H.; Huang, K. Oncogenic role of kinesin proteins and targeting kinesin therapy. Cancer Sci. 2013, 104, 651-656. [CrossRef] [PubMed]

26. Fan, X.; Wang, X.; Zhu, H.; Wang, W.; Zhang, S.; Wang, Z. KIF2A overexpression and its association with clinicopathologic characteristics and unfavorable prognosis in colorectal cancer. Tumour Biol. 2015, 36, 8895-8902. [CrossRef]

27. Manning, C.S.; Hooper, S.; Sahai, E.A. Intravital imaging of SRF and Notch signalling identifies a key role for EZH2 in invasive melanoma cells. Oncogene 2015, 34, 4320-4332. [CrossRef] [PubMed]

28. Madhavan, J.; Mitra, M.; Mallikarjuna, K.; Pranav, O.; Srinivasan, R.; Nagpal, A.; Venkatesan, P.; Kumaramanickavel, G. KIF14 and E2F3 mRNA expression in human retinoblastoma and its phenotype association. Mol. Vis. 2009, 15, 235-240. [PubMed] 
29. Li, Y.; Lu, W.; Chen, D.; Boohaker, R.J.; Zhai, L.; Padmalayam, I.; Wennerberg, K.; Xu, B.; Zhang, W. KIFC1 is a novel potential therapeutic target for breast cancer. Cancer Biol. 2015, 16, 1316-1322. [CrossRef]

30. Kato, T.; Wada, H.; Patel, P.; Hu, H.P.; Lee, D.; Ujiie, H.; Hirohashi, K.; Nakajima, T.; Sato, M.; Kaji, M.; et al. Overexpression of KIF23 predicts clinical outcome in primary lung cancer patients. Lung Cancer 2016, 92, 53-61. [CrossRef]

31. Suzuki, N.; Hazama, S.; Ueno, T.; Matsui, H.; Shindo, Y.; Iida, M.; Yoshimura, K.; Yoshino, S.; Takeda, K.; Oka, M. A phase I clinical trial of vaccination with KIF20A-derived peptide in combination with gemcitabine for patients with advanced pancreatic cancer. J. Immunother. 2014, 37, 36-42. [CrossRef] [PubMed]

32. Markowski, J.; Oczko-Wojciechowska, M.; Gierek, T.; Jarzab, M.; Paluch, J.; Kowalska, M.; Wygoda, Z.; Pfeifer, A.; Tyszkiewicz, T.; Jarzab, B.; et al. Gene expression profile analysis in laryngeal cancer by high-density oligonucleotide microarrays. J. Physiol. Pharm. 2009, 60 (Suppl. 1), 57-63.

33. Sun, X.; Jin, Z.; Song, X.; Wang, J.; Li, Y.; Qian, X.; Zhang, Y.; Yin, Y. Evaluation of KIF23 variant 1 expression and relevance as a novel prognostic factor in patients with hepatocellular carcinoma. BMC Cancer 2015, 15, 961. [CrossRef]

34. Zhang, X.; Ma, C.; Wang, Q.; Liu, J.; Tian, M.; Yuan, Y.; Li, X.; Qu, X. Role of KIF2A in the progression and metastasis of human glioma. Mol. Med. Rep. 2016,13, 1781-1787. [CrossRef]

35. Takahashi, S.; Fusaki, N.; Ohta, S.; Iwahori, Y.; Iizuka, Y.; Inagawa, K.; Kawakami, Y.; Yoshida, K.; Toda, M. Downregulation of KIF23 suppresses glioma proliferation. J. Neurooncol. 2012, 106, 519-529. [CrossRef]

36. Chen, S.; Han, M.; Chen, W.; He, Y.; Huang, B.; Zhao, P.; Huang, Q.; Gao, L.; Qu, X.; Li, X. KIF1B promotes glioma migration and invasion via cell surface localization of MT1-MMP. Oncol. Rep. 2016, 35, 971-977. [CrossRef]

37. Schmidt, M.; Mock, A.; Jungk, C.; Sahm, F.; Ull, A.T.; Warta, R.; Lamszus, K.; Gousias, K.; Ketter, R.; Roesch, S.; et al. Transcriptomic analysis of aggressive meningiomas identifies PTTG1 and LEPR as prognostic biomarkers independent of WHO grade. Oncotarget 2016, 7, 14551-14568. [CrossRef]

38. Steiner, H.H.; Bonsanto, M.M.; Beckhove, P.; Brysch, M.; Geletneky, K.; Ahmadi, R.; Schuele-Freyer, R.; Kremer, P.; Ranaie, G.; Matejic, D.; et al. Antitumor vaccination of patients with glioblastoma multiforme: A pilot study to assess feasibility, safety, and clinical benefit. J. Clin. Oncol. 2004, 22, 4272-4281. [CrossRef]

39. Lucanus, A.J.; Yip, G.W. Kinesin superfamily: Roles in breast cancer, patient prognosis and therapeutics. Oncogene 2018, 37, 833-838. [CrossRef]

40. Rath, O.; Kozielski, F. Kinesins and cancer. Nat. Rev. Cancer 2012, 12, 527-539. [CrossRef]

41. Baas, P.W.; Matamoros, A.J. Inhibition of kinesin-5 improves regeneration of injured axons by a novel microtubule-based mechanism. Neural Regen. Res. 2015, 10, 845-849. [CrossRef]

42. Jiang, M.; Zhuang, H.; Xia, R.; Gan, L.; Wu, Y.; Ma, J.; Sun, Y.; Zhuang, Z. KIF11 is required for proliferation and self-renewal of docetaxel resistant triple negative breast cancer cells. Oncotarget 2017, 8, 92106-92118. [CrossRef]

43. Daigo, K.; Takano, A.; Thang, P.M.; Yoshitake, Y.; Shinohara, M.; Tohnai, I.; Murakami, Y.; Maegawa, J.; Daigo, Y. Characterization of KIF11 as a novel prognostic biomarker and therapeutic target for oral cancer. Int. J. Oncol. 2018, 52, 155-165. [CrossRef]

44. Zhou, J.; Chen, W.R.; Yang, L.C.; Wang, J.; Sun, J.Y.; Zhang, W.W.; He, Z.Y.; Wu, S.G. KIF11 functions as an oncogene and is associated with poor outcomes from breast cancer. Cancer Res. Treat. 2018. [CrossRef]

45. Schneider, M.A.; Christopoulos, P.; Muley, T.; Warth, A.; Klingmueller, U.; Thomas, M.; Herth, F.J.; Dienemann, H.; Mueller, N.S.; Theis, F.; et al. AURKA, DLGAP5, TPX2, KIF11 and CKAP5: Five specific mitosis-associated genes correlate with poor prognosis for non-small cell lung cancer patients. Int. J. Oncol. 2017, 50, 365-372. [CrossRef]

46. Imai, T.; Oue, N.; Nishioka, M.; Mukai, S.; Oshima, T.; Sakamoto, N.; Sentani, K.; Matsusaki, K.; Yoshida, K.; Yasui, W. Overexpression of KIF11 in gastric cancer with intestinal mucin phenotype. Pathobiology 2017, 84, 16-24. [CrossRef]

47. Shah, J.J.; Kaufman, J.L.; Zonder, J.A.; Cohen, A.D.; Bensinger, W.I.; Hilder, B.W.; Rush, S.A.; Walker, D.H.; Tunquist, B.J.; Litwiler, K.S.; et al. A Phase 1 and 2 study of Filanesib alone and in combination with low-dose dexamethasone in relapsed/refractory multiple myeloma. Cancer 2017, 123, 4617-4630. [CrossRef] 
48. Hernandez-Garcia, S.; San-Segundo, L.; Gonzalez-Mendez, L.; Corchete, L.A.; Misiewicz-Krzeminska, I.; Martin-Sanchez, M.; Lopez-Iglesias, A.A.; Algarin, E.M.; Mogollon, P.; Diaz-Tejedor, A.; et al. The kinesin spindle protein inhibitor filanesib enhances the activity of pomalidomide and dexamethasone in multiple myeloma. Haematologica 2017, 102, 2113-2124. [CrossRef]

49. LoRusso, P.M.; Goncalves, P.H.; Casetta, L.; Carter, J.A.; Litwiler, K.; Roseberry, D.; Rush, S.; Schreiber, J.; Simmons, H.M.; Ptaszynski, M.; et al. First-in-human phase 1 study of filanesib (ARRY-520), a kinesin spindle protein inhibitor, in patients with advanced solid tumors. Investig. New Drugs 2015, 33, 440-449. [CrossRef]

50. Chari, A.; Htut, M.; Zonder, J.A.; Fay, J.W.; Jakubowiak, A.J.; Levy, J.B.; Lau, K.; Burt, S.M.; Tunquist, B.J.; Hilder, B.W.; et al. A phase 1 dose-escalation study of filanesib plus bortezomib and dexamethasone in patients with recurrent/refractory multiple myeloma. Cancer 2016, 122, 3327-3335. [CrossRef]

51. Gomez, H.L.; Philco, M.; Pimentel, P.; Kiyan, M.; Monsalvo, M.L.; Conlan, M.G.; Saikali, K.G.; Chen, M.M.; Seroogy, J.J.; Wolff, A.A.; et al. Phase I dose-escalation and pharmacokinetic study of ispinesib, a kinesin spindle protein inhibitor, administered on days 1 and 15 of a 28-day schedule in patients with no prior treatment for advanced breast cancer. Anticancer Drugs 2012, 23, 335-341. [CrossRef]

52. Burris, H.A., 3rd; Jones, S.F.; Williams, D.D.; Kathman, S.J.; Hodge, J.P.; Pandite, L.; Ho, P.T.; Boerner, S.A.; Lorusso, P. A phase I study of ispinesib, a kinesin spindle protein inhibitor, administered weekly for three consecutive weeks of a 28-day cycle in patients with solid tumors. Investig. New Drugs 2011, 29, 467-472. [CrossRef] [PubMed]

53. Tang, P.A.; Siu, L.L.; Chen, E.X.; Hotte, S.J.; Chia, S.; Schwarz, J.K.; Pond, G.R.; Johnson, C.; Colevas, A.D.; Synold, T.W.; et al. Phase II study of ispinesib in recurrent or metastatic squamous cell carcinoma of the head and neck. Investig. New Drugs 2008, 26, 257-264. [CrossRef]

54. Lee, C.W.; Belanger, K.; Rao, S.C.; Petrella, T.M.; Tozer, R.G.; Wood, L.; Savage, K.J.; Eisenhauer, E.A.; Synold, T.W.; Wainman, N.; et al. A phase II study of ispinesib (SB-715992) in patients with metastatic or recurrent malignant melanoma: A National Cancer Institute of Canada Clinical Trials Group trial. Investig. New Drugs 2008, 26, 249-255. [CrossRef]

55. Blagden, S.P.; Molife, L.R.; Seebaran, A.; Payne, M.; Reid, A.H.; Protheroe, A.S.; Vasist, L.S.; Williams, D.D.; Bowen, C.; Kathman, S.J.; et al. A phase I trial of ispinesib, a kinesin spindle protein inhibitor, with docetaxel in patients with advanced solid tumours. Br. J. Cancer 2008, 98, 894-899. [CrossRef]

56. Holen, K.D.; Belani, C.P.; Wilding, G.; Ramalingam, S.; Volkman, J.L.; Ramanathan, R.K.; Vasist, L.S.; Bowen, C.J.; Hodge, J.P.; Dar, M.M.; et al. A first in human study of SB-743921, a kinesin spindle protein inhibitor, to determine pharmacokinetics, biologic effects and establish a recommended phase II dose. Cancer Chemother. Pharm. 2011, 67, 447-454. [CrossRef]

57. Bongero, D.; Paoluzzi, L.; Marchi, E.; Zullo, K.M.; Neisa, R.; Mao, Y.; Escandon, R.; Wood, K.; O'Connor, O.A. The novel kinesin spindle protein (KSP) inhibitor SB-743921 exhibits marked activity in in vivo and in vitro models of aggressive large B-cell lymphoma. Leuk. Lymphoma 2015, 56, 2945-2952. [CrossRef]

58. O'Connor, O.A.; Gerecitano, J.; Van Deventer, H.; Hainsworth, J.; Zullo, K.M.; Saikali, K.; Seroogy, J.; Wolff, A.; Escandon, R. The addition of granulocyte-colony stimulating factor shifts the dose limiting toxicity and markedly increases the maximum tolerated dose and activity of the kinesin spindle protein inhibitor SB-743921 in patients with relapsed or refractory lymphoma: Results of an international, multicenter phase I/II study. Leuk. Lymphoma 2015, 56, 2585-2591. [CrossRef]

59. Hu, J.R.; Liu, M.; Wang, D.H.; Hu, Y.J.; Tan, F.Q.; Yang, W.X. Molecular characterization and expression analysis of a KIFC1-like kinesin gene in the testis of Eumeces chinensis. Mol. Biol. Rep. 2013. [CrossRef]

60. Tan, F.Q.; Ma, X.X.; Zhu, J.Q.; Yang, W.X. The expression pattern of the C-terminal kinesin gene kifc1 during the spermatogenesis of Sepiella maindroni. Gene 2013, 532, 53-62. [CrossRef]

61. Farina, F.; Pierobon, P.; Delevoye, C.; Monnet, J.; Dingli, F.; Loew, D.; Quanz, M.; Dutreix, M.; Cappello, G. Kinesin KIFC1 actively transports bare double-stranded DNA. Nucleic Acids Res. 2013, 41, 4926-4937. [CrossRef] [PubMed]

62. Sati, L.; Seval-Celik, Y.; Unek, G.; Korgun, E.T.; Demir, R. The presence of kinesin superfamily motor proteins KIFC1 and KIF17 in normal and pathological human placenta. Placenta 2009, 30, 848-854. [CrossRef] [PubMed]

63. Yang, W.X.; Sperry, A.O. C-terminal kinesin motor KIFC1 participates in acrosome biogenesis and vesicle transport. Biol. Reprod. 2003, 69, 1719-1729. [CrossRef] 
64. Han, J.; Wang, F.; Lan, Y.; Wang, J.; Nie, C.; Liang, Y.; Song, R.; Zheng, T.; Pan, S.; Pei, T.; et al. KIFC1 regulated by miR-532-3p promotes epithelial-to-mesenchymal transition and metastasis of hepatocellular carcinoma via gankyrin/AKT signaling. Oncogene 2018. [CrossRef]

65. Fu, X.; Zhu, Y.; Zheng, B.; Zou, Y.; Wang, C.; Wu, P.; Wang, J.; Chen, H.; Du, P.; Liang, B.; et al. KIFC1, a novel potential prognostic factor and therapeutic target in hepatocellular carcinoma. Int. J. Oncol. 2018, 52, 1912-1922. [CrossRef]

66. Xiao, Y.X.; Shen, H.Q.; She, Z.Y.; Sheng, L.; Chen, Q.Q.; Chu, Y.L.; Tan, F.Q.; Yang, W.X. C-terminal kinesin motor KIFC1 participates in facilitating proper cell division of human seminoma. Oncotarget 2017, 8, 61373-61384. [CrossRef]

67. Imai, T.; Oue, N.; Yamamoto, Y.; Asai, R.; Uraoka, N.; Sentani, K.; Yoshida, K.; Yasui, W. Overexpression of KIFC1 and its association with spheroid formation in esophageal squamous cell carcinoma. Pathol. Res. Pr. 2017, 213, 1388-1393. [CrossRef]

68. Xiao, Y.X.; Yang, W.X. KIFC1: A promising chemotherapy target for cancer treatment? Oncotarget 2016, 7, 48656-48670. [CrossRef]

69. Oue, N.; Mukai, S.; Imai, T.; Pham, T.T.; Oshima, T.; Sentani, K.; Sakamoto, N.; Yoshida, K.; Yasui, W. Induction of KIFC1 expression in gastric cancer spheroids. Oncol. Rep. 2016, 36, 349-355. [CrossRef]

70. Liu, Y.; Zhan, P.; Zhou, Z.; Xing, Z.; Zhu, S.; Ma, C.; Li, Q.; Zhu, Q.; Miao, Y.; Zhang, J.; et al. The overexpression of KIFC1 was associated with the proliferation and prognosis of non-small cell lung cancer. J. Thorac. Dis. 2016, 8, 2911-2923. [CrossRef]

71. Li, G.; Chong, T.; Yang, J.; Li, H.; Chen, H. Kinesin motor protein KIFC1 is a target protein of miR-338-3p and associated with poor prognosis and progression of renal cell carcinoma. Oncol. Res. 2018. [CrossRef]

72. Sekino, Y.; Oue, N.; Shigematsu, Y.; Ishikawa, A.; Sakamoto, N.; Sentani, K.; Teishima, J.; Matsubara, A.; Yasui, W. KIFC1 induces resistance to docetaxel and is associated with survival of patients with prostate cancer. Urol. Oncol. 2017, 35, 31 e13-31 e20. [CrossRef]

73. Xue, D.; Cheng, P.; Han, M.; Liu, X.; Xue, L.; Ye, C.; Wang, K.; Huang, J. An integrated bioinformatical analysis to evaluate the role of KIF4A as a prognostic biomarker for breast cancer. Onco Targets 2018, 11, 4755-4768. [CrossRef]

74. Gao, H.; Chen, X.; Cai, Q.; Shang, Z.; Niu, Y. Increased KIF4A expression is a potential prognostic factor in prostate cancer. Oncol Lett. 2018, 15, 7941-7947. [CrossRef]

75. Matsumoto, Y.; Saito, M.; Saito, K.; Kanke, Y.; Watanabe, Y.; Onozawa, H.; Hayase, S.; Sakamoto, W.; Ishigame, T.; Momma, T.; et al. Enhanced expression of KIF4A in colorectal cancer is associated with lymph node metastasis. Oncol Lett. 2018, 15, 2188-2194. [CrossRef]

76. Wang, H.; Lu, C.; Li, Q.; Xie, J.; Chen, T.; Tan, Y.; Wu, C.; Jiang, J. The role of Kif4A in doxorubicin-induced apoptosis in breast cancer cells. Mol. Cells 2014, 37, 812-818. [CrossRef]

77. Taniwaki, M.; Takano, A.; Ishikawa, N.; Yasui, W.; Inai, K.; Nishimura, H.; Tsuchiya, E.; Kohno, N.; Nakamura, Y.; Daigo, Y. Activation of KIF4A as a prognostic biomarker and therapeutic target for lung cancer. Clin. Cancer Res. 2007, 13, 6624-6631. [CrossRef]

78. Yang, Z.; Li, C.; Yan, C.; Li, J.; Yan, M.; Liu, B.; Zhu, Z.; Wu, Y.; Gu, Q. KIF14 promotes tumor progression and metastasis and is an independent predictor of poor prognosis in human gastric cancer. Biochim. Biophys. Acta Mol. Basis Dis. 2019, 1865, 181-192. [CrossRef]

79. Zhang, Y.; Yuan, Y.; Liang, P.; Zhang, Z.; Guo, X.; Xia, L.; Zhao, Y.; Shu, X.S.; Sun, S.; Ying, Y.; et al. Overexpression of a novel candidate oncogene KIF14 correlates with tumor progression and poor prognosis in prostate cancer. Oncotarget 2017, 8, 45459-45469. [CrossRef]

80. Qiu, H.L.; Deng, S.Z.; Li, C.; Tian, Z.N.; Song, X.Q.; Yao, G.D.; Geng, J.S. High expression of KIF14 is associated with poor prognosis in patients with epithelial ovarian cancer. Eur. Rev. Med. Pharm. Sci. 2017, 21, 239-245.

81. O'Hare, M.; Shadmand, M.; Sulaiman, R.S.; Sishtla, K.; Sakisaka, T.; Corson, T.W. Kif14 overexpression accelerates murine retinoblastoma development. Int. J. Cancer 2016, 139, 1752-1758. [CrossRef]

82. Sheng, Y.; Wang, W.; Hong, B.; Jiang, X.; Sun, R.; Yan, Q.; Zhang, S.; Lu, M.; Wang, S.; Zhang, Z.; et al. Upregulation of KIF20A correlates with poor prognosis in gastric cancer. Cancer Manag. Res. 2018, 10, 6205-6216. [CrossRef] 
83. Kawai, Y.; Shibata, K.; Sakata, J.; Suzuki, S.; Utsumi, F.; Niimi, K.; Sekiya, R.; Senga, T.; Kikkawa, F.; Kajiyama, H. KIF20A expression as a prognostic indicator and its possible involvement in the proliferation of ovarian clearcell carcinoma cells. Oncol. Rep. 2018, 40, 195-205. [CrossRef] [PubMed]

84. Lu, M.; Huang, X.; Chen, Y.; Fu, Y.; Xu, C.; Xiang, W.; Li, C.; Zhang, S.; Yu, C. Aberrant KIF20A expression might independently predict poor overall survival and recurrence-free survival of hepatocellular carcinoma. IUBMB Life 2018, 70, 328-335. [CrossRef] [PubMed]

85. Duan, J.; Huang, W.; Shi, H. Positive expression of KIF20A indicates poor prognosis of glioma patients. Onco Targets 2016, 9, 6741-6749. [CrossRef] [PubMed]

86. Puttmann, S.; Senner, V.; Braune, S.; Hillmann, B.; Exeler, R.; Rickert, C.H.; Paulus, W. Establishment of a benign meningioma cell line by hTERT-mediated immortalization. Lab. Invest. 2005, 85, 1163-1171. [CrossRef] [PubMed]

87. Mawrin, C. Animal models of meningiomas. Chin. Clin. Oncol. 2017, 6, S6. [CrossRef]

88. Sahm, F.; Schrimpf, D.; Jones, D.T.; Meyer, J.; Kratz, A.; Reuss, D.; Capper, D.; Koelsche, C.; Korshunov, A.; Wiestler, B.; et al. Next-generation sequencing in routine brain tumor diagnostics enables an integrated diagnosis and identifies actionable targets. Acta Neuropathol. 2016, 131, 903-910. [CrossRef]

(C) 2019 by the authors. Licensee MDPI, Basel, Switzerland. This article is an open access article distributed under the terms and conditions of the Creative Commons Attribution (CC BY) license (http://creativecommons.org/licenses/by/4.0/). 